\title{
Impact of Food Fortification on Child Growth and Development during Complementary Feeding
}

\author{
David Omondi Okeyo \\ Kenya Nutritionists and Dieticians Institute, Nairobi, Kenya
}

\section{Key Messages}

- Effective feeding practices at early stages of life have a positive impact on the growth and development of a child as evidenced by a growing body of literature on negative growth outcome with inappropriate feeding practices.

- Fortification of commonly used food vehicles provides an opportunity for increasing nutrient intake during infancy and has the potential to improve growth. Fortification, however, depends on relevant food vehicles during complementary feeding programs. Those food vehicles include staple foods (e.g., rice), condiments (soy sauce and sugar), and processed foods (infant complementary foods).

- Most studies still reflect outcomes that do not demonstrate direct cause and effect relationships between fortification and growth but rather evidence of implied linkages.

- Important caution dwells on the fact that fortification should be evidence based and implemented based on initial screening processes or observable clinical signs for potential deficiencies. Key players in the intervention matrix should avoid blanket or mass fortification without informed choices backed by evidence.

\section{Keywords}

Food · Fortification - Child growth - Development .

Complementary feeding

\begin{abstract}
There appears to be increasing evidence of the relationship between infant feeding practices and growth during infancy. Effective complementary feeding has demonstrated an observable positive effect on the linear growth of a child within the first 24 months of life. It appears that improved complementary feeding is directly proportional to the linear growth of a child. Fortification of commonly used food vehicles provides an opportunity for increasing nutrient intake during infancy and has the potential to improve growth and development dimensions. This review scanned through 186 articles from common search engines, mainly PubMed, BioMed Central, and Google Scholar. The result based on a systematic review of articles which met the minimum selection criteria identified milk, iodine, maize meal porridge, and vegetable oils as recurring fortification vehicles in the context of complementary feeding. A significant impact of fortification on linear and cognitive growth was demonstrated recurrently across the included empirical studies. However, the review reflects outcomes that still do not demonstrate direct cause and effect relationships but rather implied meaning in the relationship matrix.

(c) 2018 S. Karger AG, Basel
\end{abstract}

\section{KARGER}

(c) 2018 S. Karger AG, Basel

E-Mail karger@karger.com

www.karger.com/anm
David Omondi Okeyo, MSc, PhD, MPH, RPHNS

Kenya Nutritionists and Dieticians Institute

PO Box 20436-00100 Nairobi (Kenya)

E-Mail jandigwa@yahoo.co.uk 


\section{Introduction}

Effective feeding practices at early stages of life have a positive impact on the growth and development of a child. There is a growing body of literature that significantly demonstrates a negative growth outcome with inappropriate feeding practices $[1,2]$. Introducing additional foods other than breast milk poses a high risk of deficiencies at the early stage of life [3] and more specific for 1,000 days.

A causal link between infant feeding practices and growth during infancy is unquestionable and many studies have had significant proof of the relationship [4-6]. These linkages have been demonstrated particularly in both cross-sectional studies $[7,8]$ and longitudinal models [9]. Both designs have strong weight behind determination of causation and had a significant confirmation of the link between feeding practices and growth of a child leading to strong internal consistency.

Growth faltering is widespread during the critical formative years of child growth [10-12] leading to both short-term and long-term consequences in relation to physical and mental development [13]. Effective complementary feeding has demonstrated an observable positive effect on the linear growth of a child within the first 24 months of life [14]. Somehow, it appears that improved complementary feeding is directly proportional to the linear growth of a child [15]. These empirical attestations con-

\section{Improved complementary feeding is directly proportional to the linear growth of a child}

\section{Methodology}

The study design adopted the use of a mini systematic review critically assessing previous empirical studies (Fig. 1). PubMed, Google Scholar, and BioMed Central were the main databases used to search for relevant articles using keywords such as "food fortification and growth" and "food fortification, growth and compensatory feeding". Objective evaluation was applied in critical scanning of each article based on the thematic focus of the articles in relation to the topic of the study. Issues that were weighted for purposes of inclusion surrounded the complementary feeding, fortification in the context of young firm the need for interventions that target growth enhancement during complementary feeding.

Existing literature confirms that growth impairment can be experienced first immediately after birth and may continue all through 18 months $[16,17]$. This period includes the complementary feeding phase characterized by variations across households. Growth failure may be caused by an inadequate intake of macronutrients and micronutrients [18], which is sometimes found to be common during complementary feeding. Many causes of growth retardation which occur during complementary feeding often reflected as stunting have demonstrated reversibility. The provision of multiple micronutrient supplementation during 12 months corrected child growth in Mexican children [11]. This outcome was also reflected in cognitive development [19], where micronutrient supplementation could improve cognitive indices with characteristics of impairment.

Fortification of commonly used food vehicles provides an opportunity for increasing nutrient intake dur- child feeding as well as physical and cognitive growth. The review scanned through 186 articles closely related to the topic and out of these a few articles were selected after meeting the threshold of set criteria to argue on the empirical case. The results identified milk, iodine, maize meal, and vegetable oil as the commonly used food vehicles for fortification.

\section{Results and Discussion}

\section{Child Growth during Complementary Feeding}

Introduction of complementary foods after 6 months of exclusive breastfeeding is crucial for optimal growth and development of a child within the 1,000 golden days [23]. Complementary feeding contributes to child growth and development between 6 and 24 months [24], making it a critical factor in the etiology of malnutrition. Some studies have confirmed the existence of problems characterized by suboptimal complementary feeding practices in West Africa posing a major challenge towards the 
Fig. 1. Systematic review matrix in the context of fortification and growth of a child. Keywords used: fortification + growth; fortification + development; fortification + growth + development; fortification + growth + development + children .

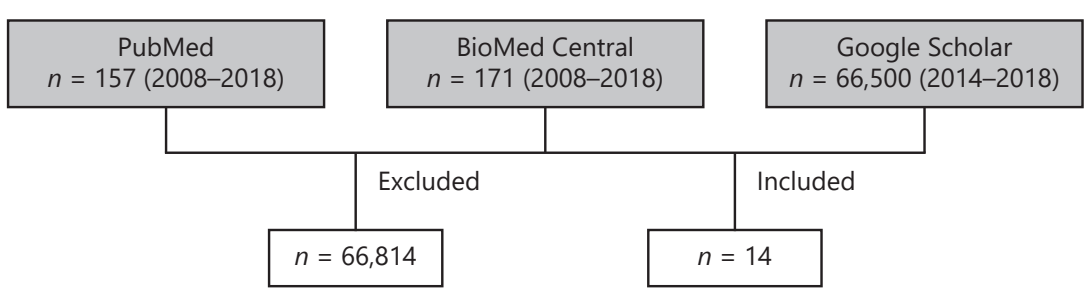

Articles had fortification in the title but content irrelevant of linkage to growth
Content had linkage to growth parameters achievement of a minimally acceptable diet [25]. Given the importance of complementary feeding in the physical growth and cognitive development of a child, there appear to be serious gaps when normal diet provisions become a usual practice.

During complementary feeding, the high incidence of growth faltering is probably the result of questionable meal quality, quantity, and frequency [26]. These components of complementary feeding attempt to suggest a critical focus on the quality and adequacy of complementary foods for maximum supply of required nutrients. These results may exhibit adverse consequences on growth and development. Somehow a study of this nature seems to demonstrate a persistent positive effect on intelligence development [27]. In addition, this reaffirms the contribution of fortification to the cognitive development of children.

\section{Fortification during Complementary Feeding:}

\section{Growth and Development Concept}

Fortification is one of the many public health interventions towards mitigating micronutrient malnutrition as well as poor growth and development of children [28]. Fortification refers to the deliberate addition of nutrients to food to meet the demand of increased intake requirements of a targeted population. In many cases, fortification targets restoring nutrients lost during processing, enhancing nutrients lost during processing, enhancing nutrient levels of food vehicles that have limited content than what is required, and adding nutrients not usually present in food to some commonly consumed food vehicles for the purposes of boosting intake of that particular nutrient $[29,30]$.

Successful fortification during complementary feeding depends on food vehicles commonly used as comple- ments. Nearly all food vehicles used as basic minimum for complementary feeding reviewed from previous literature focus on micronutrient fortification [31-33]. However, it is widely known in science that vitamins and minerals play a major role in metabolic processes and are very critical in macronutrient metabolism. Therefore, the hidden role in growth is unquestionable.

\section{Impact of Fortification on Growth and Development:}

\section{Systematic Review}

Complementary feeding has a significant attributable effect on child growth and thus opens up a gateway for fortification [34]. Many studies have demonstrated the impact of fortification on the physical and emotional development of children.

A study conducted to investigate whether multi-micronutrient food fortification could improve the cognition of school children through a systematic review process revealed a positive correlation and subsequent effect [35]. Similarly, another study made an attempt to test the effect of milk fortified with iodine on the cognitive ability of children, where a considerable favorable impact was realized on cognitive function of school children [36]. This relationship is not far from the truth as iodine is needed for the production of thyroid hormone that is essential for growth.

A randomized controlled study involving 419 infants aged 6 months was conducted for 9 months with a singleblind technique to establish the effect of animal source food and micronutrient fortification in complementary food products on linear growth [37]. The final outcome of this study revealed the potential of micronutrient fortification. The outcome somehow concurred with another study which demonstrated a positive effect on linear growth driven by multi-micronutrient home fortifica- 
Table 1. Selected studies showing the impact of food fortification on growth [39-52]

\begin{tabular}{|c|c|c|}
\hline Authors [Ref.] & Focus & Methods and results \\
\hline $\begin{array}{l}\text { Bouhouch } \\
\text { et al. [39] }\end{array}$ & $\begin{array}{l}\text { Effect of fortified milk on growth and } \\
\text { nutritional status in young children: a } \\
\text { systematic review and meta-analysis }\end{array}$ & $\begin{array}{l}\text { Design: Five databases were searched for randomized controlled trials using fortified } \\
\text { milk against control milk in young children. Outcomes were growth, body } \\
\text { composition, and/or biochemical markers. Pooled differences in means were } \\
\text { calculated for continuous outcomes and odds ratios for binary outcomes. } \\
\text { Results: Fortified milk was found to be an effective source of complementary } \\
\text { nutrition to supplement children in need when consumed in appropriate amounts in } \\
\text { addition to a normal diet. It appears that further research on fortified milk is } \\
\text { warranted before making global recommendations on benefits for growth and } \\
\text { nutritional outcomes in young children. }\end{array}$ \\
\hline $\begin{array}{l}\text { Farebrother } \\
\text { et al. [40] }\end{array}$ & $\begin{array}{l}\text { Iodized salt and iodine supplements for } \\
\text { prenatal and postnatal growth: a rapid } \\
\text { scoping of existing systematic reviews }\end{array}$ & $\begin{array}{l}\text { Design: All English-language systematic reviews reporting on the effect of iodine } \\
\text { supplementation or fortification in any form, dose, or regimen on any iodine-related } \\
\text { health outcomes (including but not limited to growth) were included. } \\
\text { Results: Although } 5 \text { reviews prespecified inclusion of growth outcomes, none } \\
\text { provided synthesized evidence on the effects of iodine supplementation or } \\
\text { fortification on prenatal and postnatal somatic growth. }\end{array}$ \\
\hline $\begin{array}{l}\text { Kuriyan } \\
\text { et al. [41] }\end{array}$ & $\begin{array}{l}\text { The effects of regular consumption of a } \\
\text { multiple micronutrient fortified milk } \\
\text { beverage on the micronutrient status of } \\
\text { school children and on their mental and } \\
\text { physical performance }\end{array}$ & $\begin{array}{l}\text { Design: A randomized, double-blind placebo-controlled study design was used with } \\
\text { normal healthy children from low- to middle-income families, aged } 7-10 \text { years } \\
\text { randomly assigned to receive either a multi-micronutrient-fortified or an unfortified } \\
\text { milk-based control drink. } \\
\text { Results: Overall improvement in cognitive and physical performance was seen in } \\
\text { both groups at end line, with no significant differences between the groups. }\end{array}$ \\
\hline $\begin{array}{l}\text { Sazawal } \\
\text { et al. [42] }\end{array}$ & $\begin{array}{l}\text { Compliance with home-based } \\
\text { fortification strategies for delivery of } \\
\text { iron and zinc: its effect on hematological } \\
\text { and growth markers among 6- to } \\
24 \text {-month-old children in north India }\end{array}$ & $\begin{array}{l}\text { Design: A total of } 292 \text { children were randomly allocated to receive either rice-based } \\
\text { fortified complementary food and nutrition education }(\mathrm{Cf}=101) \text {, sprinkle and } \\
\text { nutrition education }(\mathrm{Mp}=97) \text {, or nutrition education alone as control }(\mathrm{Ed}=94) \text {. } \\
\text { Results: Fortified complementary food had higher compliance than sprinkle and is a } \\
\text { suitable delivery mechanism for iron and zinc in preschool children. }\end{array}$ \\
\hline $\begin{array}{l}\text { Semba } \\
\text { et al. [ } 43]\end{array}$ & $\begin{array}{l}\text { Consumption of micronutrient-fortified } \\
\text { milk and noodles is associated with } \\
\text { lower risk of stunting in preschool-aged } \\
\text { children in Indonesia }\end{array}$ & $\begin{array}{l}\text { Design: Consumption of fortified milk and fortified noodles was assessed in children } \\
6-59 \text { months of age from } 222,250 \text { families living in rural areas and } 79,940 \text { families } \\
\text { living in urban slum areas in Indonesia. } \\
\text { Results: The consumption of fortified milk and noodles is associated with decreased } \\
\text { odds of stunting among Indonesian children. }\end{array}$ \\
\hline $\begin{array}{l}\text { Pérez-Expósito } \\
\text { and Klein [44] }\end{array}$ & $\begin{array}{l}\text { Impact of fortified blended food aid } \\
\text { products on nutritional status of infants } \\
\text { and young children in developing } \\
\text { countries }\end{array}$ & $\begin{array}{l}\text { Design: The review was conducted to examine the impact that fortified blended } \\
\text { foods used in humanitarian relief programs have had on the health and nutritional } \\
\text { status of infants and young children with moderate malnutrition, or at risk of } \\
\text { undernutrition, in developing countries. Published articles were identified using } \\
\text { electronic databases and general Web searches. } \\
\text { Results: Positive effects on recovery from moderate acute malnutrition and weight } \\
\text { gain were observed when fortified blended foods were distributed as dietary } \\
\text { supplements. }\end{array}$ \\
\hline $\begin{array}{l}\text { Muthayya } \\
\text { et al. [45] }\end{array}$ & $\begin{array}{l}\text { Effect of fortification with multiple } \\
\text { micronutrients and } \mathrm{n}-3 \text { fatty acids on } \\
\text { growth and cognitive performance in } \\
\text { Indian schoolchildren: the CHAMPION } \\
\text { (Children's Health and Mental } \\
\text { Performance Influenced by Optimal } \\
\text { Nutrition) study }\end{array}$ & $\begin{array}{l}\text { Design: In a 2-by-2 factorial, double-blind, randomized controlled trial, } 598 \text { children } \\
\text { aged } 6 \text { - } 10 \text { years were individually allocated to } 1 \text { of } 4 \text { intervention groups to receive } \\
\text { foods fortified with either } 100 \text { or } 15 \% \text { of the recommended dietary allowance of } \\
\text { micronutrients in combination with either } 900 \mathrm{mg} \text { alpha-linolenic acid plus } 100 \mathrm{mg} \\
\text { docosahexaenoic acid or } 140 \mathrm{mg} \text { alpha-linolenic acid for } 12 \text { months. } \\
\text { Results: The high-micronutrient treatment was more beneficial for linear growth } \\
\text { than the low-micronutrient treatment. }\end{array}$ \\
\hline $\begin{array}{l}\text { Silva } \\
\text { et al. [46] }\end{array}$ & $\begin{array}{l}\text { Growth of preschool children was } \\
\text { improved when fed an iron-fortified } \\
\text { fermented milk beverage supplemented } \\
\text { with Lactobacillus acidophilus }\end{array}$ & $\begin{array}{l}\text { Design: The fermented milk beverage was fortified with iron amino acid chelate } \\
\text { ( } 3 \mathrm{mg} \text { iron per } 80 \mathrm{~mL} \text { ) and supplemented with Lactobacillus acidophilus (test) or not } \\
\text { (control). The beverage was fed to } 190 \text { children aged 2-5 years for a duration of } 101 \\
\text { days. } \\
\text { Results: The fortified beverage contributed to improved nutrient intake and } \\
\text { nutritional status of the preschool children. The higher demand and mobilization of } \\
\text { nutrients to offset growth may have contributed to maintain blood parameters at } \\
\text { borderline levels. }\end{array}$ \\
\hline
\end{tabular}


Table 1 (continued)

\begin{tabular}{|c|c|c|}
\hline Authors [Ref.] & Focus & Methods and results \\
\hline $\begin{array}{l}\text { Manger } \\
\text { et al. [47] }\end{array}$ & $\begin{array}{l}\text { A micronutrient-fortified seasoning } \\
\text { powder reduces morbidity and } \\
\text { improves short-term cognitive function } \\
\text { but has no effect on anthropometric } \\
\text { measures in primary school children in } \\
\text { northeast Thailand: a randomized } \\
\text { controlled trial }\end{array}$ & $\begin{array}{l}\text { Design: In a randomized controlled trial of } 569 \text { children aged } 5.5-13.4 \text { years from } 10 \\
\text { schools, we compared the efficacy of a seasoning powder fortified with or without } \\
5 \mathrm{mg} \mathrm{Fe,} 5 \mathrm{mg} \mathrm{Zn,} 50 \mu \mathrm{g} \text { I, and } 270 \mu \mathrm{g} \text { vitamin A per serving consumed with a school } \\
\text { lunch } 5 \text { days/week. } \\
\text { Results: The intervention had no statistically significant effect on anthropometric } \\
\text { measures over } 31 \text { weeks, but reduced the incidence of respiratory-related illnesses } \\
\text { (rate ratio [RR]: } 0.83 \text {; } 95 \% \mathrm{CI}: 0.73,0.94 \text { ), symptoms of runny nose (RR: } 0.80 ; 95 \% \\
\text { CI: } 0.70,0.92 \text { ), cough (RR: } 0.80 ; 95 \% \mathrm{CI}: 0.66,0.96 \text { ), and diarrhea (RR: } 0.38 ; 95 \% \mathrm{CI} \text { : } \\
0.16,0.90 \text { ). }\end{array}$ \\
\hline $\begin{array}{l}\text { Faber } \\
\text { et al. [48] }\end{array}$ & $\begin{array}{l}\text { Effect of a fortified maize meal porridge } \\
\text { on anemia, micronutrient status, and } \\
\text { motor development of infants }\end{array}$ & $\begin{array}{l}\text { Design: Infants aged 6-12 months }(n=361) \text { were randomly assigned to receive } \\
\text { either the fortified or unfortified porridge for } 6 \text { months. Growth was assessed as a } \\
\text { secondary outcome. Primary and secondary outcomes were assessed at baseline and } \\
6 \text { months. } \\
\text { Results: This low-cost fortified porridge can potentially have a significant effect in } \\
\text { reducing anemia and improving iron status and motor development of infants in } \\
\text { poor settings. }\end{array}$ \\
\hline $\begin{array}{l}\text { Nesamvuni } \\
\text { et al. [49] }\end{array}$ & $\begin{array}{l}\text { Fortification of maize meal improved } \\
\text { the nutritional status of } 1 \text { - to } 3 \text {-year-old } \\
\text { African children }\end{array}$ & $\begin{array}{l}\text { Design: A randomized parallel intervention study was used in which } 21 \text { experimental } \\
\text { children and their families received maize meal fortified with vitamin A, thiamine, } \\
\text { riboflavin, and pyridoxine, while } 23 \text { control children and their families received } \\
\text { unfortified maize meal. } \\
\text { Results: Despite a small sample size, this study showed positive effects of a vitamin- } \\
\text { fortified maize meal on weight gain and some variables of vitamin A status in 1- to } \\
\text { 3-year-old African children. }\end{array}$ \\
\hline $\begin{array}{l}\text { Mason } \\
\text { et al. [50] }\end{array}$ & $\begin{array}{l}\text { Iodine fortification is related to } \\
\text { increased weight-for-age and } \\
\text { birthweight in children in Asia }\end{array}$ & $\begin{array}{l}\text { Design: The use of iodated salt in relation to anthropometric data was examined } \\
\text { from recent survey data. } \\
\text { Results: The apparent growth response to iodine may reflect functional effects of } \\
\text { mild deficiency, which is widespread, possibly including effects on brain } \\
\text { development. }\end{array}$ \\
\hline $\begin{array}{l}\text { Vaidya } \\
\text { et al. [51] }\end{array}$ & $\begin{array}{l}\text { Vegetable oil-fortified feeds in the } \\
\text { nutrition of very low birthweight babies }\end{array}$ & $\begin{array}{l}\text { Design: Two kinds of oils, (i) Polyunsaturated fatty acids (PUFA)-rich safflower oil } \\
\text { and (ii) medium chain triglyceride (MCT)-rich coconut oil, were added to the feeds } \\
\text { of } 46 \text { very low birthweight babies to see if such a supplementation is capable of } \\
\text { enhancing their weight gain. Twenty-two well-matched babies who received no } \\
\text { fortification served as controls. } \\
\text { Results: The mean weight gain per day, weight gain per kg per day }(19.47+\text { or }-8.67 \\
\text { g/day or } 13.91 \mathrm{~g} / \text { day), and mean weekly increment in skinfold thickness were } \\
\text { significantly greater in the coconut oil group as compared to controls ( } p=0.05) \text {. }\end{array}$ \\
\hline $\begin{array}{l}\text { Muhilal } \\
\text { et al. [52] }\end{array}$ & $\begin{array}{l}\text { Vitamin A-fortified monosodium } \\
\text { glutamate and health, growth, and } \\
\text { survival of children: a controlled field } \\
\text { trial }\end{array}$ & $\begin{array}{l}\text { Design: In a controlled trial, fortification of commercially marketed monosodium } \\
\text { glutamate with vitamin A improved serum vitamin A levels of young children and } \\
\text { the vitamin A content of breast milk of lactating women. } \\
\text { Results: Linear growth was greater among program than among control children at } \\
\text { every age. }\end{array}$ \\
\hline
\end{tabular}

tion among refugee children [38]. These two studies appear to confirm the impact fortification has on the linear growth of children during complementary feeding. However, fortification not only contributes positively to linear growth and physical development. Some studies have focused on home fortification of complementary feeding and its effect on intellectual development of children in a large sample survey $(n=1,478)$. In Table 1 , relevant selected studies are shown to demonstrate the existing relationship between fortification, growth, and development.

Impact of Food Fortification on Child Growth and Development

\section{Conclusion and Recommendation}

A close analysis of these studies reviewed demonstrated convergence, with a common understanding of the positive correlation between food fortification and the growth of children. Growth parameters consistently range from physical, motor, to cognitive development across the studies. This review demonstrates the growing literature on the impact of fortification on growth and development during complementary feeding. It identified growth from the perspective of physical and cognitive dimensions. Micronutrients are major fortifiers in 
common food vehicles, which justifies that fortification is rather a metabolic process in growth and development.

The result based on articles which met the minimum selection criteria identified milk, iodine, maize meal porridge, and vegetable oils as recurring fortification vehicles in the context of complementary feeding. However, the review reflects outcomes that still do not demonstrate direct cause and effect relationships between fortification and growth but rather evidence of implied linkages. Therefore, fortification should be evidence based and im- plemented based on initial screening processes. Key players in the intervention matrix should avoid blanket or mass fortification without informed choices.

\section{Disclosure Statement}

The author of this publication received an honorarium from Nestlé Nutrition Institute. The terms of this arrangement have been reviewed and approved by the Kenya Nutritionists and Dieticians Institute in accordance with its policy on objectivity in research.

\section{References}

1 Bhutta ZA, Ahmed T, Black RE, Cousens S, Dewey K, Giugliani E, et al: What works? Interventions for maternal and child undernutrition and survival. Lancet 2008;371:417440.

2 Kumar D, Goel NK, Mittal PC, Misra P: Influence of infant-feeding practices on nutritional status of under-five children. Indian J Pediatr 2006;73:417-421.

3 Brown KH, Creed-Kanashiro H, Dewey KG: Optimal complementary feeding practices to prevent childhood malnutrition in developing countries. Food Nutr Bull 1995;16:164e.

4 Ruel MT, Menon P: Child feeding practices are associated with child nutritional status in Latin America: innovative uses of the demographic and health surveys. J Nutr 2002;132: 1180-1187.

5 Sawadogo PS, Martin-Prevel Y, Savy M, et al: An infant and child feeding index is associated with the nutritional status of 6- to 23month-old children in rural Burkina Faso. J Nutr 2006;136:656-663.

6 Ntab B, Simondon KB, Milet J, et al: A young child feeding index is not associated with height-for-age or height velocity in rural Senegalese children. J Nutr 2005;135:457-464.

7 Marquis GS, Habicht J-P, Lanata CF, Black RE, Rasmussen K: Association of breastfeeding and stunting in Peruvian toddlers: an example of reverse causality. Int J Epidemiol 1998;26:349-356.

8 Marquis GS, Diaz J, Bartolini R, De Kanashiro HC, Rasmussen K. Recognizing the reversible nature of child-feeding decisions: breastfeeding, weaning, and re-lactation patterns in a shanty town community in Lima. Soc Sci Med 1998;47:645-646.

9 Hop LT, Gross R, Giay T, Sastroamidjojo S, Schultink W, Lang NT: Premature complementary feeding is associated with poorer growth of Vietnamese children. J Nutr 2000; 130:2683-2690.

10 Shrimpton R, Victora CG, de Onis M, Lima RC, Blossner M, Glugston G: Worldwide timing of growth faltering: implications for nutrition interventions. Pediatr 2001;107:1-7.
11 Rivera JA, Gonzalez-Cossio T, Flores M, Romero M, Rivera M, Tellez-Rojo MM, Rosado JL, Brown KH: Multiple micronutrient supplementation increases the growth of Mexican infants. Am J Clin Nutr 2001;74:657-663.

12 Scrimshaw NS: Community-Based Longitudinal Nutrition and Health Studies: Classical Examples from Guatemala, Haiti and Mexico. Boston, International Foundation for Developing Countries, 1995.

13 Lozoff B, Georgieff MK: Iron deficiency and brain development. Semin Pediatr Neurol 2006; 13:158-165

14 Lartey A, Manu A, Brown KH, Peerson JM, Dewey KG: A randomized, community-based trial of the effects of improved, centrally processed complementary foods on growth and micronutrient status of Ghanaian infants from 6 to 12 mo of age. Am J Clin Nutr 1999; 70:391-404.

15 Penny ME, Creed-Kanashiro HM, Robert RC, Narro MR, Caulfield LE, Black RE: Effectiveness of an educational intervention delivered through the health services to improve nutrition in young children: a cluster-randomized controlled trial. Lancet 2005;365:1863-1872.

16 Waterlow JC: Post-neonatal mortality in the Third World. Lancet 1988;ii:1303.

17 Martorell R, Khan LK, Schroeder DG: Reversibility of stunting: epidemiological findings in children from developing countries. Eur J Clin Nutr 1994;48(suppl 1):S45-S57.

18 Golden MH: The role of individual nutrient deficiencies in growth retardation of children as exemplified by zinc and protein; in Waterlow JC (ed): Linear Growth Retardation in Less Developed Countries. New York, Raven Press, 1988, pp 143-163.

19 Grantham-McGregor S, Walker S, Powell C: Nutritional supplementation and mental development. Lancet 1991;338:758.

20 Angeles-Agdeppa I, Magsadia CR, Capanzana MV: Fortified juice drink improved iron and zinc status of schoolchildren. Asia Pac J Clin Nutr 2011;20535-543.
21 Das JK, Salam RA, Kumar R, Bhutta ZA: Micronutrient fortification of food and its impact on woman and child health: a systematic review. Syst Rev 2013;2:67.

22 Bhandari N, Taneja S, Mazumder S, Bahl R, Fontaine O, Bhan MK: Adding zinc to supplemental iron and folic acid does not affect mortality and severe morbidity in young children. J Nutr 2007;137:112-117.

23 Pem D: factors affecting early childhood growth and development: golden 1,000 days. Adv Practice Nurs 2015;1:101.

24 National Statistics Bureau: Bhutan Multiple Indicator Survey, 2010. Thimphu, National Statistics Bureau, 2011.

25 Issaka AI, Agho KE, Page AN, Burns PL, Stevens GJ, Dibley MJ. The problem of suboptimal complementary feeding practices in West Africa: what is the way forward? Matern Child Nutr 2015;11(suppl 1):53-60.

26 Awogbenja MD, Ugwuona FU: Feeding practices and nutritional status of under-five children in Nasarawa State, Nigeria. PAT 2010;6: 23-35.

27 Chen CM, Wang YY, Chang SY: Effect of inhome fortification of complementary feeding on intellectual development of Chinese children. Biomed Environ Sci 2010;23:83-91.

28 Mannar MG, Sankar R: Micronutrient fortification of foods-rationale, application and impact. Indian J Pediatr 2004;71:997-1002.

29 Meenakshi JV, Johnson NL, Manyong VM, Degroote $\mathrm{H}$, Javelosa J, et al: How cost-effective is biofortification in combating micronutrient malnutrition? an ex ante assessment. World Dev 2010;38:64-75.

30 Ottaway PB: Food Fortification and Supplementation: Technological, Safety and Regulatory Aspects. Cambridge, Woodhead Publishing Ltd, 2008.

31 Caballero B, Allen L, Prentice A: Encyclopedia of Human Nutrition, ed 2. Oxford, Elsevier Ltd, 2005.

32 Vinodkumar M, Rajagopalan S: Multiple micronutrient fortification of salt. Eur J Clin Nutr 2009;63:437-445. 
33 Melse-Boonstra A, de Pee S, Martini E, Halati S, Sari M, et al: The potential of various foods to serve as a carrier for micronutrient fortification, data from remote areas in Indonesia. Eur J Clin Nutr 2000;54:822-827.

34 Chang SY, He W Chen CM: Complementary feeding and growth of infant and young child in China. Biomed Environ Sci 2008;21:264268.

35 Best C, Neufingerl N, Del Rosso JM, Transler C, van den Briel T, Osendarp S: Can multimicronutrient food fortification improve the micronutrient status, growth, health, and cognition of schoolchildren? A systematic review. Nutr Rev 2011;69:186-204.

36 Zahrou FE, Azlaf M, El Menchawy I, El Mzibri M, El Kari K, El Hamdouchi A, Mouzouni FZ, Barkat A, Aguenaou H: Fortified iodine milk improves iodine status and cognitive abilities in schoolchildren aged 7-9 years living in a rural mountainous area of Morocco. J Nutr Metab 2016;2016:8468594.

37 Skau JK, Touch B, Chhoun C, Chea M, Unni US, Makurat J, Filteau S, Wieringa FT, Dijkhuizen MA, Ritz C, Wells JC, Berger J, Friis H, Michaelsen KF, Roos N: Effects of animal source food and micronutrient fortification in complementary food products on body composition, iron status, and linear growth: a randomized trial in Cambodia. Am J Clin Nutr 2015;101:742-751.

38 Bilukha O, Howard C, Wilkinson C, Bamrah S, Husain F: Effects of multimicronutrient home fortification on anemia and growth in Bhutanese refugee children. Food Nutr Bull 2011;32:264-276.

39 Bouhouch RR, El-Fadeli S, Andersson M, Aboussad A, Chabaa L, Zeder C, Kippler M, Baumgartner J, Sedki A, Zimmermann MB: Effects of wheat-flour biscuits fortified with iron and EDTA, alone and in combination, on blood lead concentration, iron status, and cognition in children: a double-blind randomized controlled trial. Am J Clin Nutr 2016;104:1318-1326.

40 Farebrother J, Naude CE, Nicol L, Andersson $\mathrm{M}$, Zimmermann MB: Iodised salt and iodine supplements for prenatal and postnatal growth: a rapid scoping of existing systematic reviews. Nutr J 2015;14:89.

41 Kuriyan R, Thankachan P, Selvam S, Pauline M, Srinivasan K, Kamath-Jha S, Vinoy S, Misra S, Finnegan Y, Kurpad AV: The effects of regular consumption of a multiple micronutrient fortified milk beverage on the micronutrient status of school children and on their mental and physical performance. Clin Nutr 2016;35:190-198.

42 Sazawal S, Dhingra P, Dhingra U, Gupta S, Iyengar V, Menon VP, Sarkar A, Black RE: Compliance with home-based fortification strategies for delivery of iron and zinc: its effect on haematological and growth markers among 6-24 months old children in north India. J Health Popul Nutr 2014;32:217-226.

43 Semba RD, Moench-Pfanner R, Sun K, de Pee S, Akhter N, Rah JH, Campbell AA, Badham J, Bloem MW, Kraemer K: Consumption of micronutrient-fortified milk and noodles is associated with lower risk of stunting in preschool-aged children in Indonesia. Food Nutr Bull 2011;32:347-353.

44 Pérez-Expósito AB, Klein BP: Impact of fortified blended food aid products on nutritional status of infants and young children in developing countries. Nutr Rev 2009;67:706-718.

45 Muthayya S, Eilander A, Transler C, Thomas $\mathrm{T}$, van der Knaap HC, Srinivasan K, van Klinken BJ, Osendarp SJ, Kurpad AV: Effect of fortification with multiple micronutrients and n-3 fatty acids on growth and cognitive performance in Indian schoolchildren: the CHAMPION (Children's Health and Mental Performance Influenced by Optimal Nutri- tion) Study. Am J Clin Nutr 2009;89:17661775.

46 Silva MR, Dias G, Ferreira CL, Franceschini SC, Costa NM: Growth of preschool children was improved when fed an iron-fortified fermented milk beverage supplemented with Lactobacillus acidophilus. Nutr Res 2008;28:226-232.

47 Manger MS, McKenzie JE, Winichagoon P, Gray A, Chavasit V, Pongcharoen T, Gowachirapant S, Ryan B, Wasantwisut E, Gibson RS: A micronutrient-fortified seasoning powder reduces morbidity and improves short-term cognitive function but has no effect on anthropometric measures in primary school children in northeast Thailand: a randomized controlled trial. Am J Clin Nutr 2008;87:1715-1722.

48 Faber M, Kvalsvig JD, Lombard CJ, Benadé AJ: Effect of a fortified maize-meal porridge on anemia, micronutrient status, and motor development of infants. Am J Clin Nutr 2005; 82:1032-1039.

49 Nesamvuni AE, Vorster HH, Margetts BM, Kruger A: Fortification of maize meal improved the nutritional status of 1-3-year-old African children. Public Health Nutr 2005;8: 461-467.

50 Mason JB, Deitchler M, Gilman A, Gillenwater K, Shuaib M, Hotchkiss D, Mason K, Mock $\mathrm{N}$, Sethuraman K: Iodine fortification is related to increased weight-for-age and birthweight in children in Asia. Food Nutr Bull 2002;23:292-308.

51 Vaidya UV, Hegde VM, Bhave SA, Pandit AN: Vegetable oil fortified feeds in the nutrition of very low birthweight babies. Indian Pediatr 1992;29:1519-1527.

52 Muhilal, Permeisih D, Idjradinata YR Muherdiyantiningsih, Karyadi D: Vitamin Afortified monosodium glutamate and health, growth, and survival of children: a controlled field trial. Am J Clin Nutr 1988;48:1271-1276. 